\title{
Redistributive Impact of Differential Mortality in the French Pay-As-You-Go System
}

\section{Thomas Barnay}

ERUDITE, Faculté de sciences économiques et de gestion, Université Paris 12 Val de Marne, 61, avenue du Général de Gaulle, Mail des mèches, Créteil 94010, France.

E-mail: barnay@univ-paris12.fr

The aim of this article is to determine the actuarial financial profitability and the "actuarial" age of retirement for men retiring above the age of 55 with a single pension from the private sector and no interruption to their payment career. France is characterized by considerable differences in mortality between social categories and these lead to significant redistributions. The application of the actuarial fairness concept would lead to a noticeable difference in the age of retirement by social category in order to compensate for these mortality differences.

The Geneva Papers (2007) 32, 570-582. doi:10.1057/palgrave.gpp.2510145

Keywords: redistribution; retirement; differential mortality; actuarial fairness

\section{Introduction}

Many empirical studies have attempted to measure the redistributive effects of the pay-as-you-go system using the concept of actuarial fairness. This concept refers to a situation of equality between the present value of pension benefits and the present value of pension contributions during the life cycle. Legros ${ }^{1}$ distinguishes four types of study: study of representative agents; ${ }^{2}$ microsimulation; ${ }^{3}$ critical age; ${ }^{4}$ and prospective projection. ${ }^{5}$ From the earliest studies in the $1980 \mathrm{~s}$ the social redistribution observed most frequently is from the poorer classes towards the better-off classes. ${ }^{6}$ Studies outside France have confirmed this anti-redistributive phenomenon: in the U.K., Creedy et al., ${ }^{7}$ in Australia, Atkinson et al. ${ }^{8}$ and in the U.S., Coronado et al. ${ }^{9}$

However, these anti-redistributive effects from the poorer classes towards the well-off do not seem to be replicated if the totality of transfers made in the pension

\footnotetext{
${ }^{1}$ Legros (1994).

${ }^{2}$ Lagarde (1985); Dutailly (1988); Aubert (1999); Assous et al. (2001).

${ }^{3}$ Hurd and Shoven (1985); Creedy et al. (1993); Colin et al. (1999); Bonnet and Mahieu (2000); Vincent and Walraët (2003).

${ }^{4}$ Kessler and Masson (1985).

${ }^{5}$ Kotlikoff (1992).

${ }^{6}$ Lagarde (1985).

${ }^{7}$ Creedy et al. (1993).

${ }^{8}$ Atkinson et al. (1996).

${ }^{9}$ Coronado et al. (2000).
} 
system are analysed. The IRR (internal rates of return), that is, the interest rates which respect actuarial fairness, as calculated by Colin et al., ${ }^{10}$ show that redistribution takes place above all from men ( 2.2 per cent) to women (3.3 per cent). These differences are due to the differences in life expectancy but also to redistribution mechanisms (particularly family benefits and the minimum contribution) that benefit women. Recent work by Vincent and Walraët ${ }^{11}$ corroborates these results. According to these authors men benefit from an internal rate of return of 2.8 per cent compared to 4 per cent for women. ${ }^{12}$ On the other hand, those with low incomes on average have a higher rate (5.9 per cent) than those of better-off individuals, although this difference changes the redistribution from men to women. In fact for the male population, the rate is more or less the same whatever the level of income.

To our knowledge no study in France has explicitly presented retirement ages which respect actuarial fairness together with differentiated probabilities of survival by profession and socio-professional categories (SPC). Hence our study aims to determine the retirement ages which would respect actuarial fairness in the absence of redistributive mechanisms for the male population (based on analysis of data from INSEE's 1996 Employment Survey). It looks at representative agents in the retired male population over 55. What we are attempting here is to take a balance sheet view of the pension system. Using a highly simplified framework, we try to illustrate the consequences of applying the concept of actuarial fairness to age at retirement.

The article is divided into three parts. The first part deals with a description of the French context. The second one aims to determine the theoretical expression of current financial value $(\mathrm{CFV})^{13}$ in relation to the concept of actuarial fairness and the characteristics of the sample and the simplifying assumptions used here. Finally, the last part presents the results: the CFV for each SPC (i.e., the age which respects actuarial fairness during the life cycle) compared to the effective age when rights are accrued for each of these categories, and the discussion.

\section{The French context}

The French pension system has a long history. The regulations of 1945 aimed to create a compulsory system guaranteeing the universality and unity of the system. The first of these aims was attained in the 1970s, but the large number of retirement schemes represented a departure from the original objectives. The system has been progressively extended by establishing specific schemes for groups not covered at the beginning (agricultural workers in 1952). Legislation $(1974,1978)$ then enabled

\footnotetext{
${ }^{10}$ Colin et al. (1999).

${ }^{11}$ Vincent and Walraët's analysis of redistribution based only on IRR was criticised by Dupuis and El Moudden (2003). The latter have reservations about the conclusions reached. In fact, IRR tell nothing about the level of pensions, only an indication of the direction of the distribution but not its level.

12 See also Bonnet and Mahieu (2000).

${ }^{13}$ This concept was developed by El Moudden-Bajram (2000).
} 
coverage of other categories (prisoners, artists, housewives in particular circumstances, etc.). For reasons often related to professional issues, the employed population does not, therefore, benefit from the same rules of access to retirement benefits. So, the average age at which a pension is claimed varies slightly by level of education, social category and the specific features of different schemes. Hence executives, self-employed and agricultural workers stop working later than manual workers. $^{14}$

Today, the French pension system is complex, with equality in the length of the required contribution period for private sector employees and civil servants (in 2008) but at the same time there is a great variety of rules governing access to pensions, and there is no private pension insurance. These are the specific features of the French system. The legal age of retirement for employees is still very low (the same for men and women, namely 60 years). Moreover, the employment rate for 55-64 year olds was 40.7 per cent in 2005 , one of the lowest in Europe. ${ }^{15}$

Length of employment is being squeezed from two sides: age of entry into the labour market is rising (23 years old) and the average age at cessation of employment is decreasing - it is 59 (differing from an average age of 62 when rights are accrued). Thus, the French labour market essentially concerns the $25-55$ years population and a new phase of transition (inactivity, preretirement, unemployment, etc.) appears between employment and retirement periods.

In this context, in order to alleviate the demographic deficit, the law of 21 August 2003 concerning pension reform focussed almost exclusively on restoring the intergenerational equilibrium. The principle of a pension system based on pay-asyou-go system was reaffirmed. The main measure was an increase in the contribution period to 41 years in 2012 (then to 42 years until 2020), and in addition an alignment of the contribution period of civil servants with that of the general scheme (private sector) will take place in 2008 (40 annual years of contributions).

The life cycle is changing between generations and also between social categories within the same generation. The least well-off categories are also those which begin work sooner and are most likely to have periods of unemployment during their career. The health status of these categories also changes most during working life.

Furthermore, France has the greatest variation in male mortality in Europe. ${ }^{16}$ In France, the mortality of manual workers is 71 per cent higher than that of non-manual workers for the population aged 45-59. This difference is twice that of many countries (Denmark, Norway, Switzerland, Italy and Portugal). Moreover, the latest study from INSEE shows that mortality differentials are widening for men, and appear to be stabilizing for women. ${ }^{17}$ For the 1991-1999 generations, the mortality differential is 7 years between executives and manual workers in the male population, compared to 3 years for women.

\footnotetext{
${ }^{14}$ Barnay (2005).

15 OECD (2006).

${ }^{16}$ Kunst et al. (2000).

${ }^{17}$ Monteil and Robert-Bobée (2005).
} 
These features of health, and of mortality in particular, result in differences in expected duration of retirement and, therefore, in redistributions of pension insurance for the life cycle.

\section{Methods and assumptions}

Actuarial fairness can be evaluated on the basis of CFV defined as the relation between the current value of benefits and the current value of contributions. We consider an individual who starts work at date $t_{0}$ within the same generation, begins retirement at date $T$, draws his first pension at date $T+1$ and dies at any time before date $N$ (the maximum age at death). The current value of contributions (updated at rate $r$ ) for the whole period of employment, limited by age at first employment $\left(t_{0}\right)$ and the age at which pension benefits are drawn $(T)$, can be summarized by the following formula:

$$
\sum_{t=t_{0}}^{T} \frac{\tau_{t} w_{t}}{(1+r)^{t}} \pi_{t}
$$

where $w_{t}$ corresponds to salary at $t, \pi_{t}$ to the probability of survival at $t$ and $\tau_{t}$ to the contribution rate at $t$. The current value of benefits relates to the second part of the life cycle between the age when benefits are drawn at retirement $(+1$ year $)$ and age at death:

$$
\sum_{t=T+1}^{N} \frac{P_{t}}{(1+r)^{t}} \pi_{t}
$$

where $P_{t}$ is the pension.

The CFV respects actuarial fairness if:

$$
\sum_{t=T+1}^{N} \frac{P_{t}}{(1+r)^{t}} \pi_{t} / \sum_{t=t_{0}}^{T} \frac{\tau_{t} w_{t}}{(1+r)^{t}} \pi_{t}=1
$$

If this ratio is greater than 1 , the pension system is profitable for the individual, whereas if the ratio is below 1 the individual has contributed more to the pension system than he has received. A certain number of simplifying hypotheses can be introduced: first we consider for calculation of the pension $(P)$ that the reference salary is equal to the salary of the last period of employment (i.e., $\left.w_{t}\right)$. We know that the level of the pension in the first year of retirement $\left(P_{t+1}\right)$ is given by the product of the last salary $\left(w_{t}\right)$ and the replacement rate $(\beta)$ (cf. Equation (4)). Moreover, we may assume a revaluation of the pension equal to a rate of growth $\rho$ (cf. Equation (5)).

Therefore we have:

and for $t>T$

$$
P_{T+1}=\beta_{T} w_{T}
$$

$$
P_{t}=(1+\rho)^{t-T-1} P_{T+1}
$$

and therefore from Equations (4) and (5),

$$
P_{t}=(1+\rho)^{t-T-1} \beta_{T} w_{T}
$$


and considering that the salary increases at the rate $g$ (the contribution rate is taken as constant), we therefore have:

$$
w_{T}=(1+g)^{T-t_{0}} w_{t_{0}}
$$

From Equations (6) and (7) we have:

$$
w_{t_{0}}=\frac{P_{t}}{\beta_{T}(1+\rho)^{t-T-1}(1+g)^{T-t_{0}}}
$$

$\mathrm{CFV}$ is therefore given by:

$$
C F V=\frac{\sum_{t=T+1}^{N} \frac{\pi_{t} w_{t_{0}} \beta_{T}(1+\rho)^{t-T-1}(1+g)^{T-t_{0}}}{(1+r)^{t-t_{0}}}}{\sum_{t=t_{0}}^{T} \frac{\pi_{t} \tau_{T} w_{t_{0}}(1+g)^{t-t_{0}}}{(1+r)^{t-t_{0}}}}
$$

By simplifying we obtain:

$$
C F V=\frac{\sum_{t=T+1}^{N} \frac{\pi_{t} \beta_{T}(1+\rho)^{t-T-1}(1+g)^{T-t_{0}}}{(1+r)^{t-t_{0}}}}{\sum_{t=t_{0}}^{T} \frac{\pi_{t} \tau_{T}(1+g)^{t-t_{0}}}{(1+r)^{t-t_{0}}}}
$$

Cross-sectional data enable us to take representative agents alone into account even though strictly speaking calculation of the CFV should be done using micro-simulations with longitudinal data. This study addresses the calculation of the CFV for retirees using further survey data from the INSEE March 1996 employment survey. In March 1996 approximately 11,200 households consisting of at least one person over the age of 50 responded to the survey "Retirement and living conditions of persons aged 50 or more", an additional module in the annual employment survey aimed at generations born in 1946 and ordinary households living at home.

The study concerns men aged over 55, retired from the private sector (with a single pension in the general scheme) with no interruptions during their career (linear career). The choice of representative agents, which reduces the spectrum of analysis to relatively homogeneous populations, limits de facto the scope of the results. Nevertheless, this avoids the addition of more simplifying hypotheses and hence of moving away from a more "realistic" measure of the CFV. The final sample consists of 279 retirees aged over 55. On average they began their professional career at 19.1 years, worked for 40.3 years and received their retirement benefits at 59.7 years. Because the difference between age at retirement and age at liquidation of benefits is small (less than three months) for this fairly homogenous population, we assume that they are the same and that individuals pay contributions until date $T$, the age at liquidation of retirement benefits. Moreover four SPC with relatively contrasting life expectancies are studied: executives and intermediate professions on the one hand and employees on the other hand (and a distinction is made between skilled and unskilled workers). 
Table 1 Characteristics of men aged over 55 retired from the private sector (linear career)

\begin{tabular}{lcccccc}
\hline SPC & Number & $\begin{array}{c}\text { Age of } \\
\text { professional } \\
\text { career's } \\
\text { beginning }\left(t_{0}\right)\end{array}$ & $\begin{array}{c}\text { Age at } \\
\text { liquidation of } \\
\text { benefits }(T)\end{array}$ & $\begin{array}{c}\text { Number } \\
\text { of worked } \\
\text { years }\end{array}$ & $\begin{array}{c}\text { Life } \\
\text { expectancy at } \\
\text { age at } \\
\text { liquidation of } \\
\text { benefits }\end{array}$ & $\begin{array}{c}\text { Ratio } \\
\text { rexpected } \\
\text { experked years } \\
\text { duration/ } \\
\text { worked }\end{array}$ \\
\hline Executives & 63 & 21.8 & 61.0 & 39.0 & 20.5 & 0.53 \\
Intermediate & 76 & 18.3 & 58.5 & 40.6 & 20.3 & 0.50 \\
Employees & 46 & 18.4 & 60.1 & 40.3 & 18.9 & 0.47 \\
Skilled workers & 65 & 18.2 & 59.2 & 40.6 & 17.4 & 0.43 \\
Unskilled workers & 29 & 18.1 & 60.1 & 41.6 & 15.4 & 0.37 \\
Total & 279 & 19.1 & 59.7 & 40.3 & - & - \\
\hline
\end{tabular}



Source: INSEE 1996.

The life cycle of these generations of retirees is particularly varied. On average, executives retiring from the private sector, with a linear professional career, began working at 21.8 years, worked for 39 years and retired at 61 with a life expectancy at retirement of 20.5 years. In contrast, unskilled workers began their professional activity sooner (18.1 years) and retired at 60.1 but with a life expectancy at retirement that is 5 years shorter. This simple analysis of professional life shows that the ratio of retirement's expected duration/worked years (last column) is in favour of executives and intermediate categories. For an executive, one worked year allows a gain of 6.4 benefit pension's months whereas the unskilled worker gets only 4.4 months.

Taking into account the theoretical expression obtained by Equation (10), we require several variables to progress to the numerical application: probabilities of survival at each age $\left(\pi_{t}\right)$, replacement rate $(\beta)$, rate of increase of salaries $(g)$, real interest rate $(r)$, contribution rate $\left(\tau_{t}\right)$, rate of increase of pensions $(\rho)$, age at which employment starts $\left(t_{0}\right)$, age at retirement $(T)$ and maximum age at death $(N)$. The last three elements are available from the selected sample for the ages at the start of employment and at retirement and through a method for calculating probabilities of survival for the maximum age at death (described below).

It is necessary to take into account the probability of survival at each age for each SPC. However, at the beginning of this research, these data are not available. The only differentiated results are given by Mesrine. ${ }^{18}$ For each SPC, life expectancy at 35, 60 and 65 is available, as well as the probability of survival between 35 and 65 (Table 2).

We assume that the evolution of the probability of death increases geometrically from age 50 (we assume there is no mortality before age 50). Moreover, we use quarterly data in order to obtain more precise calculations of the $\mathrm{CFV}$ and the actuarial age. Finally, in this model, the maximum age at death $(N)$ is 95 years (at the end of life the survival curves converge more rapidly) and the curves' ends are skewed. We hypothesize that probabilities of death increase geometrically.

\footnotetext{
${ }^{18}$ Mesrine (1999).
} 
The Geneva Papers on Risk and Insurance - Issues and Practice

576

Table 2 Life expectancy and probability of death by social category in the male population

\begin{tabular}{lcccc}
\hline SPC in 1982 & $\begin{array}{c}\text { Life expectancy } \\
\text { at } 35\end{array}$ & $\begin{array}{c}\text { Life expectancy } \\
\text { at } 60\end{array}$ & $\begin{array}{c}\text { Life expectancy } \\
\text { at } 65\end{array}$ & $\begin{array}{c}\text { Probability of death } \\
\text { from } 35 \text { to } 65(\%)\end{array}$ \\
\hline Executives & 44.5 & 22.5 & 18.5 & 13 \\
Intermediate & 42.0 & 19.5 & 16.0 & 17 \\
Employees & 40.0 & 19.0 & 15.5 & 23 \\
Skilled workers & 39.0 & 17.5 & 14.0 & 26 \\
Unskilled workers & 37.0 & 16.0 & 13.0 & 26 \\
\hline
\end{tabular}

Source: Mesrine, 1999.

Table 3 Value of geometrical growth rate of the probability of survival $\alpha$ per SPC

\begin{tabular}{lr}
\hline & $\alpha$ \\
\hline Executives & 10,219 \\
Intermediate & 10,213 \\
Employees & 10,152 \\
Skilled workers & 10,182 \\
Unskilled workers & 10,184 \\
\hline
\end{tabular}

When $t<200$ (i.e., 50 years) the probability of death is then

When $t \geqslant 200$ then

$$
\begin{gathered}
m_{t}=0 \\
m_{t}=\alpha^{t-200} m_{200}
\end{gathered}
$$

where $t$ is expressed in number of quarters.

The coefficient $\alpha$, which defines the quarterly geometric growth rate of the probability of survival, is evaluated in Table 3. It was calculated for each group using Mesrine's data, a method of standardization based on life expectancy at 35 and 65 and probability of survival between 35 and 65 years.

The calculation gives probabilities of survival (cf. Figures 1 and 2) and life expectancies at each age. The calculation of probabilities of survival is given by the following equation:

$$
\pi_{t}=\prod_{i=200}^{t}\left(1-m_{i}\right)
$$

Moreover, the same probability of survival is assigned to the different generations of retirees. This hypothesis of constant life expectancy tends to underestimate the current total of contributions and therefore to reduce the $\mathrm{CFV}$ calculated for the younger generations.

Probabilities of survival are higher for executives and intermediate professions. The upper limit of 95 for maximum age at death for everyone means that the curves converge more rapidly. This strong assumption underestimates the survival probabilities since maximum age is 95 in this model compared to observed data in France. 




Figure 1. Probabilities of survival by SPC for each age between 50 and 95 years.

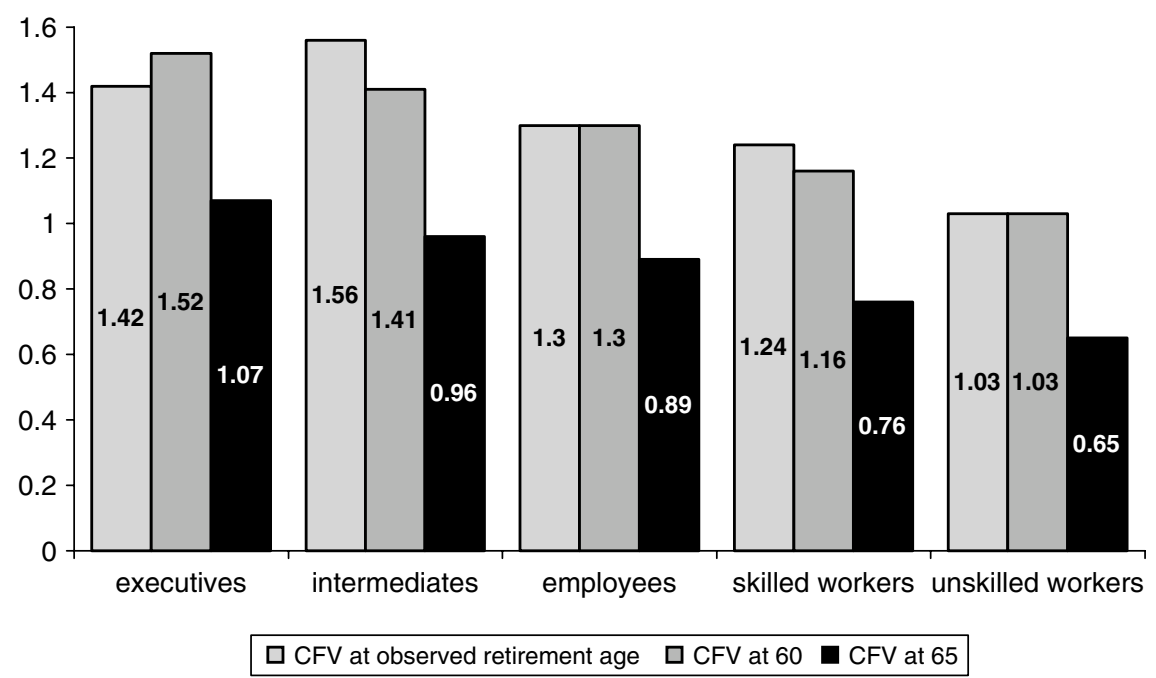

Figure 2. CFV by SPC at effective retirement age $(T)$, at 60 and at 65 .

Furthermore, the profile for employees is very distinctive. In fact this group has the lowest rate of growth in the probability of survival which means that the curves of employees and the intermediate professions cross at around 85 years. 
The replacement rate $(\beta)$ has been evaluated for the generations born in $1930 .{ }^{19}$ Hence these generations were 66 in 1996 (the date of the survey). The net replacement rate (CNAV + ARRCO-AGRIC) ranges from 59 per cent for the highest income groups ( $€ 2,000$ and above) to 100 per cent for those groups with income below $€ 1,150$. In the absence of data on the final salary of retirees, two replacement rates are considered (similar to the results cited above): 65 per cent for executives and intermediate professions, and 75 per cent for manual workers and employees.

Bayet and Demailly ${ }^{20}$ describe the evolution of salaries during the preceding 45 years. There were two phases of growth: one in which average salaries increased rapidly (more than 4 per cent in the private sector) between 1950 and the end of the 1970 s and another, up to the 1990s, of much slower growth of around 0.5 per cent. However, the generations studied here worked before 1950. It is, therefore, very difficult to establish an average rate of growth. We use an average annual growth rate of 1.5 per cent for the calculation of the CFV. Implicitly, we consider that the net salary growth rates for executives and non-executives are equal. ${ }^{21} \mathrm{We}$ fix the discount rate $(r)$, or real interest rate, at 3 per cent which corresponds to the value usually assumed in studies of this type. ${ }^{22}$ In line with the work of CNAV, the retained global contribution rate (salaried and employers) for private $\left(\tau_{t}\right)$ sector employees is 10.7 per cent (it corresponds to an average of global contribution rate taking into account changes in law since 1967). Moreover this is assumed to be constant. Finally, since 1993 pensions have been indexed with the general level of inflation whereas hitherto they had been indexed with salaries. Hence we assume that $\rho=g$.

\section{Results and discussion}

Several hypotheses are tested. The first assumes that the contribution rate (which also determines the level of benefits) is constant until the retirees die. The second aims to measure the effect of varying other parameters in the model. Figure 2 presents the calculation of the CFV by SPC at the effective age of retirement (i.e., the average age of retirement by SPC) under the hypothesis of constant contribution rates. ${ }^{23}$

All of the social categories have a CFV greater than 1 which appears to indicate that all retirees from the private sector, with a linear career profile, have a positive financial balance sheet. The most favoured groups benefit most from the pension system, thanks to their greater life expectancy (CFV at observed retirement age is equal to 1.56 for the intermediate professions, 1.42 for executives and 1.3 for employees). Unskilled workers stop working at an age which enables them to maintain more or less complete equality in flows between contributions and pensions. The observed retirement age for this group (60.1 years) is, therefore, the age of actuarial equilibrium (actuarial fairness). All else being equal, if the SPC had stopped working at 60 (minimum age in

\footnotetext{
${ }^{19}$ Assous and Coeffic (1999).

${ }^{20}$ Bayet and Demailly (1996).

${ }^{21}$ cf. Assous et al. (2001).

${ }^{22}$ Aubert (1999).

${ }^{23}$ Barnay and Jeger (2006).
} 


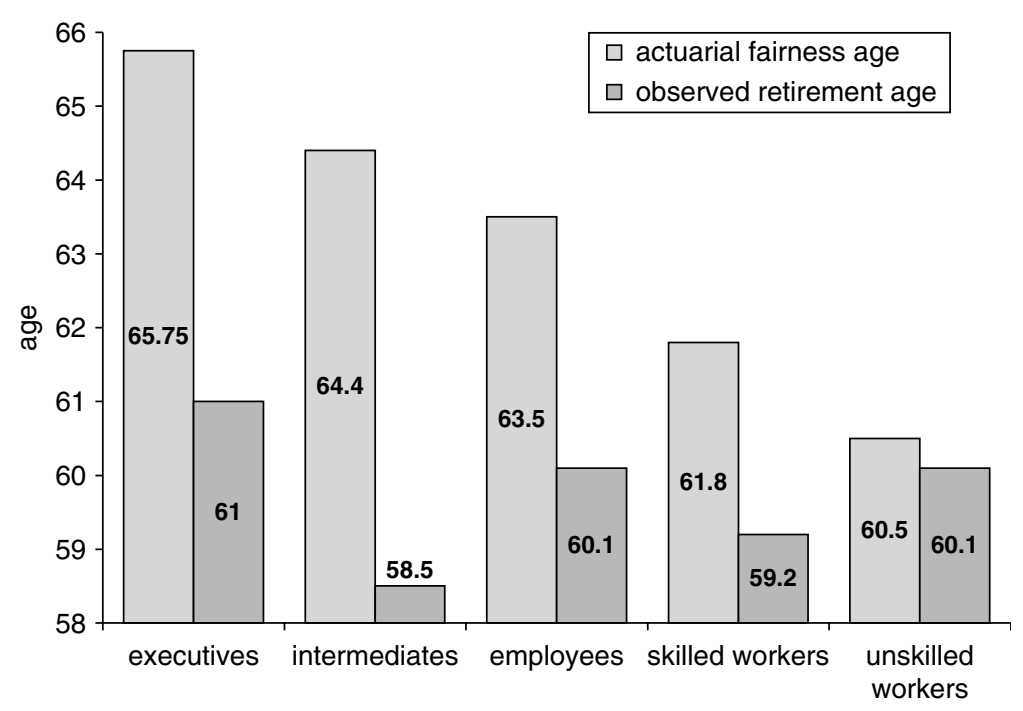

Figure 3. Differences between age of actuarial fairness and retirement age by SPC.

France till 2003), executives are the only group for which the CFV increases (in fact, the effective age of retirement is greater than 60 for executives, equal to 61). If the retirement age had been 65 for these generations, they would have been lost out except for the executives for whom the financial value would have been 1.07.

Under these conditions, at what age would retirees have had to retire such that the CFV were equal to 1 , that is, that actuarial fairness was respected?

Figure 3 shows the gap between, on the one hand, the effective retirement age and the age of actuarial fairness for each SPC, and, on the other hand, the difference between SPCs. If actuarial fairness was respected (under the hypotheses considered here), executive retirees from the private sector would have stopped working 4.75 years later (i.e., at 65.75) and the intermediate professionals 5.9 years later (at age 64.4). Taking into account differences in mortality and in behaviour in the labour market, there is a difference of 5.25 years in age at retirement of executives and unskilled workers according to the criterion of actuarial fairness. The disparities in professional careers and in longevity result in considerable differences in the age at retirement by SPC.

Lowering the interest rate by 0.5 points ( 2.5 per cent instead of 3 per cent) makes the pension system less profitable for any given contribution period. Hence the contribution period is extended by more than 2 years in order to guarantee actuarial fairness.

Differences in life expectancy are very discriminating characteristics in the calculation of actuarial fairness. If each category had the same distribution of survival probabilities as employees, the ages of actuarial fairness would be much closer (with a maximum difference of 0.75 years) (Table 4 ).

The assumptions retained for calculations of retirement age can cause a debate. For example, the social mobility (between different jobs) is increasing. Then, to 
Table 4 Retirement ages of actuarial fairness

\begin{tabular}{lccc}
\hline & $\begin{array}{c}\text { Central } \\
\text { scenario }\end{array}$ & $\begin{array}{c}\text { Fall of 0.5 points of real } \\
\text { interest rate }(2.5 \%)\end{array}$ & $\begin{array}{c}\text { Homogeneous mortality } \\
\text { (as employee) }\end{array}$ \\
\hline Executives & 65.75 & 68.00 & 62.75 \\
Intermediate & 64.40 & 66.50 & 63.50 \\
Employees & 63.50 & 65.50 & 63.50 \\
Skilled workers & 61.80 & 63.75 & 63.50 \\
Unskilled workers & 60.50 & 62.00 & 63.50 \\
\hline
\end{tabular}

differentiate life expectancies according to the social category, it would be necessary to evaluate transitions between social categories and consequences on mortality rate to avoid measure skews. In addition, the standard case selected (linear careers) becomes marginal and can become irrelevant since a majority of employees live today a transitional period between employment and retirement even if preretired and unemployed indirectly go on to contribute to the pension scheme via a fund of ageing solidarity (Fonds de solidarité vieillesse). Finally, we assume no mortality before 50 and a maximal age of 95 years, and this leads to a reduction of social differences particularly at the end of life.

If the concept of actuarial fairness is attractive, it seems that we must use it carefully for many reasons. The concept of neutrality raises problems of feasibility related to the redistributive features of pension systems based on a pay-as-you-go system (with noncontributive advantages and a ceiling on benefits), to the limited rationality of agents and to labour market constraints. ${ }^{24}$ The compatibility of individual preferences and the social optimum poses a problem. In a situation of complete freedom of choice, agents will not opt for the optimal decision (the hypothesis of myopia). They will probably leave the labour market early, underestimating their life expectancy in retirement. Moreover the rule of actuarial fairness is only possible in a purely Bismarkian universe where there is no redistribution and there are no constraints on ceasing employment. In addition, the plurality of ways to cease professional activity in France (exemptions of search for employment and disablement pensions in particular) lead the individuals in bad health to leave prematurely the labour market. Finally, from the perspective of analysing mortality differentials, the criterion of actuarial fairness ignores intra-generational or intra-group variance. With this last point, we can easily imagine potential limits opposed to the assurance principle of risk mutualization that such an indicator could have on the equality between men and women, the latter benefitting from a longer life expectancy. In France, from 2003 on, the progressive flexibility around retirement age can make it possible to approach actuarial fairness.

In spite of these difficulties, several countries recently introduced some actuarial fairness such as alternative mode, with the structural reforms aiming at exploiting the parameters such as the rate of contribution, the duration of contribution or the retirement age. Sweden and Italy thus modified extensively the access rules to retirement by removing the concept of age to the profit of a progressive retirement

${ }^{24}$ Blanchet et al. (1996). 
based on actuarial fairness. In Sweden, starting from age 61 and without limitation of age thereafter, it is possible to liquidate the pension benefits according to an actuarial rule depending on the life expectancy at the moment of the liquidation of the rights. In Italy, a similar rule was introduced, making it possible to liquidate the pension benefits between 57 and 65 years.

\section{Conclusion}

First and foremost this paper illustrates the differences between SPCs with regard to actuarial fairness for former private sector employees. The concept of actuarial fairness is used here because it is an appropriate tool for measuring intra-generational redistribution, but is not used as a norm.

These results present numerous simplifying hypotheses, and also include survival probabilities differentiated by SPC. They show that applying the concept of actuarial fairness leads to substantial differences in age at retirement by SPC, given the difference of 6 years between unskilled workers and executives indicated by these results. $^{25}$

Executives and the intermediate professions benefit much more from the pension system than manual workers. These results suggest that we should question a benefit based on a uniform age at retirement, given a context where health is now being used as a tool for regulating early retirement benefits and particularly for those groups whose health is most affected at the end of their working lives. Taking into account bad health can justify an early departure from the labour market. Several new preretirement systems allow this premature cessation of professional activity: the possibility of an early exit from labour market for certain employed persons who worked in hard conditions (CATS), for workers who were exposed to asbestos (CAATA), as well as for workers who began their professional life early implicitly meets this aim of actuarial fairness. It seems possible and equitable to compensate these financial social differences, for example, by considering the hard work conditions in France and to allow unskilled workers to leave earlier the labour force market.

\section{Acknowledgements}

I would like to thank Thomas Weitzenblum (Franche-Comte University) for his important help. I thank the referee for his useful comments. All remaining errors are mine.

\section{References}

Aubert, J-M. (1999) 'Comparaison du rendement des régimes de retraite: une approche par cas-types', Economie et Statistique 328: 61-79.

Assous, L., Bonnet, C. and Colin, C. (2001) 'Le rendement des régimes de retraite du secteur privé: une comparaison cadre-non cadre', Revue d'Economie Politique 1(March): 97-110.

Assous, L. and Coeffic, N. (1999) 'Les retraites en 1998', DREES Etudes et Résultats 43: 1-8.

\footnotetext{
${ }^{25}$ See Table 1 , column $(T)$.
} 
Atkinson, M.E., Creedy, J. and Knox, D.M. (1996) 'Alternative retirement income strategies: A cohort analysis of lifetime redistribution', The Economic Record 72(217): 97-106.

Barnay, T. and Jeger, F. (2006) 'Quels dispositifs de cessation d'activité pour les personnes en mauvaise santé?', IRDES, Questions d'Economie de la Santé, Série Résultats 108: 8.

Barnay, T. (2005) 'Santé déclarée et cessation d'activité', Revue Française d'Economie XX(2): 73-106.

Bayet, A. and Demailly, D. (1996) 'Salaires et coûts salariaux, 45 ans d'évolution', Insee première 449(May): $1-4$.

Blanchet, D., Brousse, C. and Okba, M. (1996) 'Retraite, préretraite, neutralité actuarielle et couverture du risque de chômage en fin de carrière', Economie et Statistique 291-292.

Bonnet, C. and Mahieu, R. (2000) 'Taux de rendement interne par générations des régimes obligatoires de retraite: calcul à l'aide d'un modèle de microsimulation dynamique', Revue économique 51(February): 77-95.

Colin, C., Legros, F. and Mahieu, R. (1999) 'Le rendement des régimes de retraite: une comparaison entre Fonction publique d'Etat et secteur privé', Economie et Statistique 328: 81-104.

Coronado, J-L., Fullerton, D. and Glass, T. (2000) The progressivity of social security, NBER Working paper no. 7520, Washington.

Creedy, J., Disney, R. and Whitehouse, E. (1993) 'The earning related state pension, indexation and lifetime distribution in the UK', Review of Income and Wealth 39: 257-278.

Dupuis, J.M. and El Moudden, C. (2003) 'Les difficultés de mesurer l'aspect redistributif d'un système de retraite', Economie et Statistique 366: 56-61.

Dutailly, J-C. (1988) 'Les transferts sur l'ensemble de l'existence', Economie et Statistique 210: 51-60.

El Moudden-Bajram, C. (2000) Prestations contributives et redistribution: une approche de l'équité intragénérationnelle des retraites, Doctoral thesis, University of Caen.

Hurd, M-D. and Shoven, J. (1985) 'The distributional impact of social security', in D.A. Wise (ed) Pension, Labor and Individual Choice, Chicago: University of Chicago Press, pp. 193-215.

Kessler, D. and Masson, A. (1985) Effets redistributifs du système de retraite et vieillissement individuel et collectif, Actes du Congrès international de la population, Florence, 5-12 juin.

Kotlikoff, L. (1992) Generational Accounting: Knowing Who Pays and When for What we Spend, New York: The Free Press.

Kunst, A.E., Groenhof, F. and Mackenbach, J. (2000) 'Inégalités sociales de mortalité prématurée: la France comparée aux autres pays européens', in A. Leclerc, D. Fassin, H. Grandjean, M. Kaminski, T. Lang (eds) Les inégalités sociales de santé, Paris: Inserm-La découverte, pp. 53-68.

Lagarde, F. (1985) 'La redistribution sur le cycle de vie le cas des retraites', in D. Kessler and A. Masson (eds) Cycle de vie et générations, Paris: Economica.

Legros, F. (1994) 'Caractère redistributif des systèmes de retraite', Revue économique 4: 805-817.

Mesrine, A. (1999) 'Les différences de mortalité par milieu social restent fortes', Insee Données Sociales, La société française, 228-235.

Monteil, C. and Robert-Bobée, I. (2005) 'Les différences sociales de mortalité: en augmentation chez les hommes, stables chez les femmes', Insee première 1025(June): 1-4.

OECD (2006) OECD Employment Outlook, Paris: OECD.

Vincent, A. and Walraët, E. (2003) 'La redistribution intragénérationnelle dans le système de retraite des salariés du privé: une approche par microsimulation', Economie et Statistique 366: 31-56.

\section{About the Author}

Thomas Barnay is Associate Professor of Economics at Universite Paris 12 Val de Marne. 